\title{
Corporate Boards, Audit Committees and Voluntary Disclosure: A Case Analysis on Bangladeshi Listed Companies
}

\author{
Fakrul Ahmed
}

\section{ABSTRACT}

The study tries to find the interaction of corporate disclosure and governance within the organization, focused stakeholders, and shareholders representation with internal information in the board. The paper investigates seven governance variables as the willful release of information proxy concentrated on organizational structure and functioning. Multiple regression has been performed to identify the explanatory power of the variables. The results are very much similar and consistent with the understanding that both internal and external control exist simultaneously to affect the shareholders' control to restrict each other. The results suggest that the size of the board does not affect the external control of voluntary disclosure. This paper can help to exhibit the relationship between proper and transparent corporate governance and required disclosure to reduce agency conflicts. This paper focused on the existing companies listed in the stock exchanges to identify and develop model to improve the agency setting. The paper should be interesting for the regulators, stakeholders, and practitioners to construct consistent policies with calls for more disclosure requirements in this agency setting.

Submitted : March 19, 2021

Published : April 09, 2021

ISSN: 2507-1076

DOI: $10.24018 /$ ejbmr.2021.6.2.821

Fakrul Ahmed

Department of Finance, University of Chittagong, Bangladesh.

(e-mail: fakrulahmed7667@ gmail.com)

*Corresponding Author

Keywords: Corporate Governance, Liquidity, Leverage, Bangladesh.

\section{INTRODUCTION}

Corporate Governance is a key issue in the era of industrialization and business growth. Strong corporate governance can reduce the agency problem and lead to organizational success. In this context, agency conflicts happen between large controlling shareholders and minority outside investors, with private benefits exploitation risks. Diligent monitoring activity is associated with greater transparency to the outside world. Several research types were conducted in the various countries to determine the variables affecting the governance and found some interesting results. In Bangladesh, this research is beneficial to understand the corporate structure, business strategy, and industry movement.

\section{LITERATURE REVIEW}

Informational asymmetry and probable conflict of interest between the organization's shareholders and management when there is separation of ownership and control [16]. Dominant shareholders usually concentrate the power and form management in the agency setting, the board of the organization usually formed through executive and nonexecutive directors chosen by the majority votes. In most of the cases the board of the president and chief executive officer directly supervised by the majority of insider shareholders. Through this process the interest of shareholders and management are aligned for the development of the organization. This process give birth to the agency problems as management tend to favor large stakeholders only. Minority interest often ignored and waived in front of the interests of the dominant shareholders. They tend to formulate policies to maximize their won wealth and ensure welfare excluding the minority interests and other stakeholders, i.e., the creditors and employees [14], [13]. As a result, the agency problems and conflicts of interest exists among all the shareholders.

There exit several studies regarding agency problems where the empirical evidence found that dominant shareholders control the wealth distribution as well as the dividend policy which hurts minority interests [8], [12], [7]. DeAngelo and DeAngelo [12] revealed that major shareholders in publicly listed companies obtain extra private funds by declaring special dividends, additional salaries and other compensations and transactions in network companies. In this case, banks should also try to minimize over investment and disbursement in loans \& advances to avoid liquidity risks and have an excellent corporate governance [1].

To protect the shareholders and diminish agency problems there are two control mechanisms in place such as corporate governance and voluntary disclosures. The relationship among the variables can be substitute or complementary depends on the situation. When the relation is complementary, the agency theory states that the companies 
with intensive monitoring package has higher number of voluntary disclosures [19]. The additional surveillance decreases information asymmetry and management's opportunistic behavior. When the monitoring is strong, management is afraid to restrict information flow to shareholders and draw private benefits as the detailed disclosures become compulsory. When the relation is substitutive, to reduce agency problems governance and voluntary disclosures are used as optional control mechanisms. Organizations strategically select among alternative control devices [22], [9], [2].

There are some costs associated with the voluntary disclosures. Proprietary costs and legal costs are key issues for the companies want to enhance informational symmetry and disclosure. Financing companies may also sue for any discrepancies in the information flow [23], [11]. When the informational discrepancies and agency problems are by following the channel of internal control mechanisms, the call for internal governance devices mechanisms will be irrelevant. The disclosure costs are manageable when there is economics of scale in information flow [19]. The existence and effectiveness of both the both the hypothesis of a complementary and a substitutive relationship between governance and disclosure is still debatable and existing research did not find any concrete evidence [10], [9], [15]. Majority of the researchers focused on the agency context to discuss the conflicts of interests between management and the shareholders.

\section{RESEARCH VARIABLE AND METHODOLOGY}

The existing researchers examined the correlations between the board of directors' composition and disclosure practices. The finds are very much mixed and contradictory. Several studies used percentage of independent directors with respect to total board members as the proxy for board composition [9], [21]. Some studies including the organizations in Asian countries concluded that large proportion of independent directors are correlated with lower percentage of voluntary disclosures [3], [15]. The independent directors' incentives to promote voluntary disclosure in the presence of large controlling shareholders can be related to: (1) signaling the absence of collusion with controlling shareholders and strong board leaders; (2) fostering their market value as decision experts. The expectation is a stronger independent representation in the board is positively related to the level of voluntarily disclosed information. The following hypothesis is formulated.

The size of the board is an essential factor which can influence the effectiveness. Several studies revealed that smaller boards can be more effective than large boards to reduce the agency problems. [4], [6], [17]. When there are higher board members the costs of surveillance can surpass the benefits and increase the timeframe for effective decision making. [18]. Moreover, large boards are easier for the CEO to control [16]. The studies mainly used the data from US companies to develop the view through studying the size of the boards impact on firm's market value. [24]. Recent research questions the view that larger boards are detrimental to board effectiveness and to shareholders [21], [17].

Current studies finds that the relationship between voluntary disclosure and CEO duality is very much negative and insignificant [9]. Studies with few European biotechnology companies where the power is concentrated has negative association with voluntary disclosure about intellectual capital-based information [5]. Gul and Leung [15] studying a sample of 385 Hong Kong-listed companies, show empirical evidence that the CEO duality is associated with lower voluntary disclosure levels. Following prior research, the author expects a negative relationship between CEO duality and the level of voluntary disclosure.

Multicollinearity is a situation where independent variables in a multiple regression equation are highly interrelated. A general rule regarding multicollinearity is that if the correlation between two independent variables is between -0.70 and 0.70 , there is likely no problem using both the independent variables. Fortunately for the data being analyzed, there is no significant multicollinearity problem exists. So, for our analysis, the study can use all the independent variables together.

TABLE I: EXPECTED \& CALCULATED RELATIONSHIPS

\begin{tabular}{ccc}
\hline $\begin{array}{c}\text { Independent } \\
\text { variables }\end{array}$ & $\begin{array}{c}\text { Expected } \\
\text { Relationship }\end{array}$ & $\begin{array}{c}\text { Calculated } \\
\text { Relationship }\end{array}$ \\
\hline Size & Positive (+) & Positive (+) \\
Leverage & Positive (+) & Positive (+) \\
Profitability & Positive (+) & Negative (-) \\
CEO Duality & Negative (-) & Negative (-) \\
Board Composition & Positive (+) & Positive (+) \\
Board Size & Positive (+) & Positive (+) \\
Board Activity & Positive (+) & Positive (+) \\
\hline
\end{tabular}

\begin{tabular}{|c|c|c|c|c|c|c|c|}
\hline Variables & Size & Leverage & Profitability & CEO Duality & $\begin{array}{c}\text { Board } \\
\text { Composition }\end{array}$ & Board Size & $\begin{array}{c}\text { Board } \\
\text { Activity }\end{array}$ \\
\hline Size & 1 & & & & & & \\
\hline Leverage & 0.39 & 1.00 & & & & & \\
\hline Profitability & 0.05 & -0.11 & 1.00 & & & & \\
\hline CEO Duality & 0.21 & -0.11 & -0.05 & 1.00 & & & \\
\hline Board Composition & 0.08 & 0.19 & 0.40 & 0.004 & 1.00 & & \\
\hline Board Size & -0.18 & -0.11 & 0.02 & -0.40 & -0.41 & 1.00 & \\
\hline Board Activity & 0.48 & 0.40 & -0.25 & 0.07 & -0.34 & 0.16 & 1.00 \\
\hline
\end{tabular}

\section{ANALYSIS AND FINDINGS}

In the study it is assumed that disclosure index as the dependent variable, which is affected by seven independent variables namely size, leverage, profitability, CEO duality, board composition, board size, board activity.

In the regression model, the constant 0.4283 states that when all the independent variables are zero value of $y$ that is disclosure index will be 0.428311373 .

Here the value of $\mathrm{R}^{2}=0.13$ (approximately) which means only $13 \%$ variability in dependent variable can be explained by the set of independent variables. That means $87 \%$ of variation in disclosure index is caused by random error or variables not included in the analysis. 
TABLE III: ORDINARY LEAST SQUARE METHOD

\begin{tabular}{ccccc}
\multicolumn{5}{c}{ TABLE III: ORDINARY LEAST SQUARE METHOD } \\
\hline & Coefficients & $\begin{array}{c}\text { Standard } \\
\text { Error }\end{array}$ & t Stat & P-value \\
\hline Intercept & 0.428311373 & 0.083389656 & 5.136265 & $1.49 \mathrm{E}-06$ \\
Size & 0.002714091 & 0.002823455 & 0.961266 & 0.338859 \\
Leverage & 0.03151438 & 0.055662375 & 0.56617 & 0.572613 \\
Profitability & 0.018050239 & 0.256869582 & 0.07027 & 0.944126 \\
CEO Duality & - & 0.032460225 & -1.55876 & 0.122379 \\
Board & 0.050597574 & & & \\
Composition & 0.173061702 & 0.180198349 & 0.960396 & 0.339294 \\
Board Size & 0.004175185 & 0.003289055 & 1.269418 & 0.207393 \\
Board Activity & 0.004126106 & 0.003624139 & 1.138507 & 0.257772 \\
\hline
\end{tabular}

Now, there is a problem with the R2. The number of independent variables used is a multiple regression makes the coefficient of determination larger. Each new independent variable causes the predictions to be more accurate. That is turn makes SSE smaller and SSR larger. To balance the effect that number of independent variables has on the coefficient of multiple determination has, the study used Adjusted R2. The adjusted R2 in this case is $6.5 \%$ approximately, clearly there is a significant difference exists between the $\mathrm{R} 2$ and the Adjusted R2. Actually, only $6.5 \%$ variation in the disclosure index is explained by the independent variables $93.5 \%$ is due to random error or variables not included in the analysis.

Now the author wanted to evaluate regression coefficients individually. The study conducted individual test of regression coefficients using the $\mathrm{P}$-value approach with a 5\% level of significance. So, $\alpha=0.05$.

The decision criterion is if the $\mathrm{P}$ value is less than $\alpha$ independent variable is significant. The study finds P-values from the blue shaded area of the table.

In the study all the independent variables are not significant enough to affect the disclosure index. It is clear that we should drop those variables and enter new variables in the analysis and run the regression again. It will be an iterative process.

\section{CONCLUSION}

The purpose was to determine the determinants of the disclosure index, which are the factors that significantly affect the disclosure index of a company. The study tested each independent variable individually to determine the nature of each independent variable's relationship with the dependent variable. Using the P-value approach for testing for significance, we found the variables selected for the analysis are not affecting a company's disclosure practice significantly. This means for knowing which factors affect a company's disclosure practice, one needs to incorporate new variables into the analysis, and again the whole process should be conducted.

\section{REFERENCES}

[1] Ahamed, F. (2021). Determinants of Liquidity Risk in the Commercial Banks in Bangladesh. European Journal of Business and Management Research, 6(1), 164-169.

[2] Ahmed, K., \& Courtis, J. K. (1999). Associations between corporate characteristics and disclosure levels in annual reports: A metaanalysis. The British Accounting Review, 31, 35-61.

[3] Ahmed, K., \& Nicholls, D. (1994). The impact of non-financial company characteristics on mandatory disclosure compliance in developing countries: The case of Bangladesh. The International Journal of Accounting, 29(1), 62-77.

[4] Ajinkya, B., Bhojraj, S., \& Sengupta, P. (2005). The association between outside directors, institutional investors and the properties of management earnings forecasts. Journal of Accounting Research, 43(3), 343-375

[5] Akhtaruddin, M., Hossain, M. A., Hossain, M., \& Yao, L. (2009) Corporate governance and voluntary disclosure in corporate annual reports of malaysian listed firms. Journal of Applied Management Accounting Research, 7(1), 1-21.

[6] ANDAF (Italian National Association of Chief Financial Officers). (2008). Gli annual report delle societa` italiane. Rome: ANDAF Publishing.

[7] Anderson, R. C., \& Reeb, D. M. (2004). Board composition Balancing family influence in S\&P 500 firms. Administrative Science Quarterly, 49(2), 209-237.

[8] Claessens, S., \& Djankov, S. (1999). Ownership concentration and corporate performance in the Czech Republic. Journal of comparative economics, 27(3), 498-513.

[9] Cheng, E. C., \& Courtenay, S. M. (2006). Board composition, regulatory regime and voluntary disclosure. The international journal of accounting, 41(3), 262-289.

[10] Chen, C. J., \& Jaggi, B. (2000). Association between independent nonexecutive directors, family control and financial disclosures in Hong Kong. Journal of Accounting and Public policy, 19(4-5), 285-310.

[11] Darrough, M. N., \& Stoughton, N. M. (1990). Financial disclosure policy in an entry game. Journal of accounting and economics, 12(1 3), 219-243.

[12] DeAngelo, H., \& DeAngelo, L. (2000). Controlling stockholders and the disciplinary role of corporate payout policy: A study of the Times Mirror Company. Journal of financial economics, 56(2), 153-207.

[13] Dyck, A., \& Zingales, L. (2004). Private benefits of control: An international comparison. The journal of finance, 59(2), 537-600.

[14] Fama, E. F., \& Jensen, M. C. (1983). Separation of ownership and control. The journal of law and Economics, 26(2), 301-325.

[15] Faccio, M., Lang, L. H., \& Young, L. (2001). Dividends and expropriation. American economic review, 91(1), 54-78.

[16] Gul, F. A., \& Leung, S. (2004). Board leadership, outside directors' expertise and voluntary corporate disclosures. Journal of Accounting and public Policy, 23(5), 351-379.

[17] Jensen, M. C., \& Meckling, W. H. (1976). Theory of the firm: Managerial behavior, agency costs and ownership structure. Journal of financial economics, 3(4), 305-360.

[18] Larmou, S., \& Vafeas, N. (2010). The relation between board size and firm performance in firms with a history of poor operating performance. Journal of Management \& Governance, 14(1), 61-85.

[19] La Porta, R., Lopez-de-Silanes, F., Shleifer, A., \& Vishny, R. W. (1997). Legal determinants of external finance. The journal of finance, 52(3), 1131-1150.

[20] Leftwich, R. W., Watts, R. L., \& Zimmerman, J. L. (1981). Voluntary corporate disclosure: The case of interim reporting. Journal of accounting research, 50-77.

[21] Marco Allegrini \& Giulio Greco (2011) Corporate boards, audit committees and voluntary disclosure: evidence from Italian Listed Companies, Springer Science+Business Media, LLC.

[22] Patelli, L., \& Prencipe, A. (2007). The relationship between voluntary disclosure and independent directors in the presence of a dominant shareholder. European Accounting Review, 16(1), 5-33.

[23] Rediker, K. J., \& Seth, A. (1995). Boards of directors and substitution effects of alternative governance mechanisms. Strategic management journal, 16(2), 85-99.

[24] Verrecchia, R. E. (1990). Endogenous proprietary costs through firm interdependence. Journal of accounting and economics, 12(1-3), 245250 .

[25] Yermack, D. (1996). Higher market valuation of companies with a small board of directors. Journal of financial economics, 40(2), 185 211 .

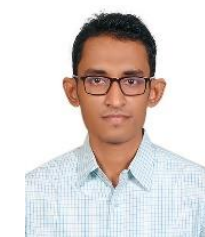

Fakrul Ahmed is a student of the Master of Business Administration Program at the University of Chittagong. The author involves in the research regarding corporate governance, liberalization, and corporate structures. Corporate governance is a key issue, and research lacks on Bangladeshi companies. The author is trying to fill the gap and help regulators formulate an effective guideline to ensure proper corporate governance. 